\title{
Pengaruh Fasilitas Belajar Terhadap Prestasi Belajar Mahasiswa Pada Perguruan Tinggi
}

\author{
Author: \\ Siti Marhamah ${ }^{1}$ \\ Agnita Yolanda ${ }^{2}$ \\ Ruri Aditya Sari ${ }^{3}$ \\ Nurismilida $^{4}$ \\ Afiliation: \\ Politeknik LP3I \\ Medan $^{1,3}$ \\ Universitas Medan \\ Area $^{2}$ \\ Universitas Islam \\ Sumatera Utara ${ }^{4}$

\section{Corresponding email} \\ agnitayo@gmail.com \\ Histori Naskah: \\ Submitted: $10-07-2021$ \\ Accepted: 21-07-2021 \\ Published: 05-08-2021

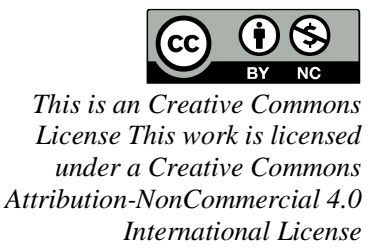

\begin{abstract}
Abstrak:
Latar belakang: Di era society 5.0, Perguruan Tinggi dituntut mampu menghasilkan mahasiswa yang kreatif dalam memecahkan permasalahan yang ada dan memberi solusi. Untuk menghasilkan mahasiswa yang kreatif, penyediaan fasilitas belajar di Perguruan Tinggi perlu di perhatikan guna meningkatkan prestasi belajar. Tujuan penulisan makalah ini untuk mendeskripsikan bagaimana Pengaruh Fasilitas Belajar Terhadap Prestasi Belajar Mahasiswa di Perguruan tinggi, yaitu ketersediaan sarana dan prasarana pendidikan.

Metode penelitian: Penelitian ini menggunakan metode kuantitatif deskriptif, dengan data yang didapat melalui observasi lapangan dan menyebarkan kuesioner kepada responden sebanyak 60 mahasiswa pada Politeknik LP3I kampus Marelan. Data diolah dengan menggunakan program SPSS Versi 25

Hasil penelitian: Hasil penelitian menunjukkan adanya fasilitas belajar pada sarana pendidikan berpengaruh terhadap prestasi belajar dan fasilitas belajar pada prasarana pendidikan tidak berpengaruh terhadap prestasi belajar. t hitung variabel Fasilitas belajar pada Sarana Pendidikan sebesar $\mathrm{t}$ hitung $3.860<\mathrm{t}$ table 1,6715 , dan pada Prasarana pendidikan diketahui nilai t hitung variabel Fasilitas belajar pada Sarana Pendidikan sebesar t hitung $2.525<\mathrm{t}$ table 1,6715 .

Kesimpulan: Disimpulkan bahwa fasilitas belajar berupa sarana pendidikan berpengaruh terhadap prestasi belajar dan fasilitas belajar berupa prasarana tidak berpengaruh terhadap prestasi belajar mahasiswa Politeknik LP3I kampus Marelan. Hal ini dikarenakan alat pelajaran, alat peraga dan media pembelajaran yang merupakan sarana dalam belajar diperlukan dalam proses pembelajaran yang dapat mempengaruhi prestasi mahasiswa.
\end{abstract}

Kata kunci: Fasilitas Belajar, Prestasi Belajar, Sarana, Prasarana, Perguruan Tinggi

\footnotetext{
Pendahuluan

Masuk Perguruan Tinggi tentunya tidak dengan biaya yang sedikit. Dalam hal ini, sebuah perguruan tinggi sudah seharusnya menyediakan fasilitas belajar yang lengkap dan berfungsi dengan baik agar dapat mendukung proses belajar mengajar di perguruan tinggi tersebut. Namun, terkadang perguruan tinggi belum mempersiapkan sarana belajar dengan baik ketika proses pembelajaran akan dimulai, misalnya seperti pendingin ruangan kelas yang tidak berfungsi dengan optimal, tidak berfungsinya komputer di laboraturium, jaringan internet yang tidak memadai, kerapihan dan kebersihan ruang baca dalam perpustakaan serta buku referensi yang tidak memadai. Hal ini tentunya menjadi perhatian setiap perguruan tinggi dalam memulai proses pembelajaran, dimana sarana dan prasarana belajar dapat mendukung proses belajar mahasiswa.
} 
Prestasi atau keberhasilan seorang mahasiswa dapat dipengaruhi oleh faktor internal yaitu berasal dari diri sendiri dan faktor eksternal yaitu berasal dari luar. Salah satu faktor eksternal yang mempengaruhi proses belajar adalah fasilitas belajar. Fasilitas belajar merupakan hal terpenting di dalam proses belajar. Apabila fasilitas belajar tidak atau kurang mendukung proses belajar, kemungkinan besar pelajar mudah jenuh dan proses penerimaan informasi dalam pembelajaran terhambat. Fasilitas pendidikan meliputi semua fasilitas yang diperlukan dalam proses belajar mengajar baik bergerak maupun tidak bergerak agar pencapaian tujuan pendidikan dapat berjalan lancar, teratur, efektif, dan efesien sehingga mahasiswa dapat mencapai hasil belajar yang optimal.

Penelitian sebelumnya menunjukkan pengaruh signifikan fasilitas belajar dan motivasi belajar terhadap prestasi belajar siswa (Herlianto et al., 2018). Dalam penelitian sebelumnya menunjukkan adanya pengaruh yang signifikan fasilitas belajar dan motivasi belajar terhadap prestasi belajar siswa. Sarana dan prasarana pendidikan meupakan material pendidikan yang sangat penting. Banyak sekolah memiliki sarana dan prasarana pendidikan yang lengkap sehingga sangat menunjang proses pendidikan disekolah (Barnawi \& Arifin, 2012). Menurut (Martin \& Fuad, 2016), Keberhasilan program pendidikan disekolah sangat dipengaruhi oleh kondisi sarana dan prasarana pendidikan yang dimiliki sekolah. Fasilitas belajar sebagai salah satu faktor eksternal yang berpengaruh terhadap prestasi belajar siswa dan fasilitas belajar termasuk didalamnya sarana dan prasarana belajar yang lengkap dan sesuai dengan kebutuhan siswa turut memberikan kontribusi terhadap pencapaian prestasi belajar siswa (Cynthia et al., 2015). Berdasarkan fenomena diatas, bagaimanakah pengaruh fasilitas belajar terhadap prestasi mahasiswa Politeknik LP3I Kampus Marelan.

\section{Studi Literatur}

Sarana pendidikan adalah semua perangkat peralatan, bahan, dan prabot yang secara langsung digunakan dalam proses pendidikan disekolah, Prasarana pendidikan adalah semua prangkat kelengkapan dasar yang secara tidak langsung menunjang pelaksanaan proses pendidikan di sekolah. Menurut Depdiknas (2008: 37) dalam (Barnawi \& Arifin, 2012) Fasilitas atau sarana belajar adalah peralatan dan perlengkapan yang secara langsung di pergunakan dalam menunjang proses belajar mengajar seperti gedung, ruang kelas, meja, kursi, serta alat-alat media pembelajaran. Menurut (Puspitasari, 2016). Media media pengajaran adalah sarana pendidikan yang berfungsi sebagai prantara (medium) dalam proses pembelajaran sehingga meningkatkan efektivitas dan efesiensi dalam mencapai tuujuan Pendidikan (Barnawi \& Arifin, 2012)

Disamping itu, alat-alat belajar merupakan faktor yang dipandang turut menentukan tingkat keberhasilan belajar siswa (Sugiyanto, 2015). Sedangkan prasarana pendidikan adalah sesuatu yang secara tidak langsung menunjang proses kegiatan belajar mengajar disekolah seperti gedung sekolah, perpustakaan, kantor sekolah yang merupakan layanan ketatausahaan untuk kelancaran proses pendidikan. Prestasi belajar adalah hasil yang diperoleh berupa kesan-kesan yang mengakibatkan perubahan dalam diri individu sebagai hasil dari aktivitas belajar. Dan prestasi belajar diartikan sama dengan hasil belajar adalah kemampuankemampuan yang dimiliki siswa setelah ia menerima pengalaman belajarnya Syaiful Bahri Djamarah dalam (Jannah, 2017).

Menurut Zuhaira Laily Kusuma dan Subhkan (2015) dalam (Herlianto et al., 2018), prestasi belajar adalah penguasaan pengetahuan atau keterampilan yang dikembangkan oleh mata pelajaran, lazimnya idtunjukkan dengan nilai tes atau angka yang diberikan oleh guru/dosen. Selanjutnya menurut Winkel (2000) dalam (Said, 2019), prestasi belajar merupakan hasil yang telah dicapai siswa baik itu berupa memahami, mengetahui, menunjukkan sikap, dan mengerjakan hal hal yang diajarkan guru atau dipelajari. 
Menurut (Dewi et al., 2017) bahwa fasilitas belajar dibagi menjadi dua yaitu sarana belajar merupakan semua perangkat peralatan, bahan dan perabot yang secara langsung digunakan dalam pendidikan seperti alat tulis, media pembelajaran, dan alat peraga; sedangkan prasarana merupakan semua perangkat kelengkapan dasar secara tidak langsung menunjang pelaksanaan proses pendidikan, contoh ruang kelas, ruang laboratorium, layanan perpustakaan dan toilet.

Adapun Faktor-faktor yang mempengaruhi prestasi belajar siswa dapat dibedakan menjadi tiga macam menurut (Syah, 2018) yaitu 1. faktor internal yaitu yakni keadaan/kondisi jasmani dan rohani siswa seperti aspek fisiologis dan aspek psikologis siswa; 2. Faktor eksternal yaitu kondisi/keadaan lingkungan disekitar siswa seperti lingkungan sosial siswa disekolah (para guru, staf administrasi dan teman-teman), Lingkungan non sosial (gedung sekolah, rumah tempat tinggal, waktu belajar yang digunakan siswa); 3. Faktor pendekatan belajar yaitu jenis upaya belajar siswa yang meliputi strategi dan metode yang digunakan sisiwa untuk melakukan kegiatan pembelajaran materi-materi pelajaran. Faktor ini sangat mempengaruhi hasil belajar siswa, sehingga semakin mendalam cara belajar siswa maka semakin baik hasilnya.

Menurut (Utami, 2020), untuk mencapai hasil belajar yang optimal perlu adanya usaha belajar dari mahasiswa untk mengembangkan pengetahuan dan keterampilan dengan memanfaatkan fasilitas sarana dan prasarana. Dalam hasil penelitiannya terdapat hubungan antara fasilitas belajar dengan prestasi belajar mahasiswa, dimana fasilitas belajar yang terdiri dari materi kuliah (modul, diktat, ppt), buku referensi, media pembelajaran, ruang kelas, ruang laboraturium dan layanan perpustakaan berpengaruh terhadap prestasi belajar yang diperoleh melalui proses belajar (Utami, 2020). Disamping itu (Amah \& Nugroho, 2015), dalam penelitiannya menyatakan fasilitas sekolah maupun lingkungan sosial secara parsial berpengaruh signifikan terhadap hasil belajar siswa dan lingkungan sosial merupakan vaiabel pemoderasi yang mampu memperkuat pengaruh fasilitas sekolah terhadap hasil belajar siswa.

Sementara itu, Menurut Nasution (2002) dalam (Said, 2019) hasil penelitiannya menunjukkan bahwa fasilitas belajar adalah tersedianya alat alat yang dapat membantu siswa belajar. Tersedianya fasilitas belajar akan memberi kemudahan dalam kegiatan belajar sehingga siswa dapat mencapai prestasi belajar yang baik. Sedangkan hasil penelitian dari (Islamiyah, 2019) mengenai pengaruh fasilitas belajar dan motivasi belajar terhadap prestasi mahasiswa jurusan Pendidikan ekonomi 2017 Universitas Negeri Surabaya, hasil penelitian menunjukkan bahwa fasilitas belajar berpengaruh positif dan signifikan terhadap prestasi belajar dengan $t$ hitung $>t$ table $(2.102>1.970)$ dengan signifikan $0.000<0.05$.

\section{Metode Penelitian}

Penelitian ini merupakan penelitian kuantitatif yaitu menganalisis data yang telah dikumpulkan melalui kuesioner yang dibagikan kepada responden. Metode analisis data yang digunakan yaitu menggunakan uji validitas dan realibilitas untuk mengukur kevalidan kuesioner serta menggunakan uji t untuk menentukan perbedaan signifikan secara statistic antara niai rata-rata suatu distribusi sampel dengan paramenter populasinya yang bertipeparametrik dan uji determinasi berdasarkan uji statistik dengan menggunakan SPSS versi 25. Skala pengukuran yang digunakan dalam penelitian ini adalah skala likert yang digunakan untuk mengukur pendapat dan persepsi seseorang atau sekelompok tentang gejala sosial.

Populasi dalam penelitian ini adalah keseluruhan dari jumlah mahasiswa/i Tingkat II dan Tingkat III Politeknik LP3I Medan Kampus Marelan yaitu berjumlah 60 orang. Tipe sampling yang digunakan dalam penelitian ini adalah sampel jenuh, dimana semua anggota populasi digunakan sebagai sampel. Teknik pengumpulan data yang digunakan dalam penelitian ini adalah menggunakan angket atau kuesioner yang disebarkan kepada 60 responden yaitu mahasiswa Politeknik LP3I Medan Kampus Marelan. Kuesioner yang disebar memuat instrumen fasilitas belajar yang terdiri dari indicator sarana dan prasarana dengan menggunakan skala likert 1 sampai dengan 5. 


\section{Hasil}

Hasil penelitian menunjukan bahwa pada variabel fasilitas belajar (X) pada indikator sarana dan prasarana pendidikan tidak memiliki pengaruh terhadap prestasi belajar (Y). Dari hasil analisis dengan menggunakan uji t memberikan hasil bahwa thitung variabel Fasilitas belajar (X) pada Sarana Pendidikan sebesar t hitung $3.860<\mathrm{t}$ table 1,6715 maka disimpulkan bahwa Ha ditolak, Ho diterima yang artinya secara parsial maka tidak ada pengaruh fasilitas belajar $(\mathrm{X})$ pada sarana pendidikan terhadap prestasi belajar $(\mathrm{Y})$. Pada Prasarana pendidikan diketahui nilai t hitung variabel Fasilitas belajar (X) pada Sarana Pendidikan sebesar t hitung $2.525<\mathrm{t}$ table 1,6715 maka disimpulkan bahwa Ha ditolak, Ho diterima yang artinya secara parsial maka tidak ada pengaruh fasilitas belajar (X)pada prasarana pendidikan terhadap prestasi belajar (Y).

Tabel 1. Uji T

\section{Coefficients $^{\mathrm{a}}$}

\begin{tabular}{|c|c|c|c|c|c|c|}
\hline \multirow{2}{*}{\multicolumn{2}{|c|}{ Model }} & \multicolumn{2}{|c|}{$\begin{array}{l}\text { Unstandardized } \\
\text { Coefficients }\end{array}$} & \multicolumn{2}{|c|}{$\begin{array}{l}\text { Standardized } \\
\text { Coefficients }\end{array}$} & \multirow[b]{2}{*}{ Sig. } \\
\hline & & $\mathrm{B}$ & Std. Error & Beta & $\mathrm{T}$ & \\
\hline 1 & (Constant) & 25.696 & 6.310 & & 4.072 & .000 \\
\hline & SaranaPendidikan & .779 & .202 & .454 & 3.860 & .000 \\
\hline a. Dep & $\begin{array}{l}\text { PrasaranaPendidikan } \\
\text { endent Variable: Prest }\end{array}$ & $\begin{array}{l}.503 \\
\text { asiBelajar }\end{array}$ & .199 & .297 & 2.525 & .014 \\
\hline
\end{tabular}

Sumber: hasil penelitian (2020), data diolah

Dari hasil analisis menggunakan uji determinasi diketahui hasil nilai koefisien determinasi pada sarana pendidikan sebesar 37,8\% dapat dikatakan sarana pendidikan berpengaruh terhadap prestasi belajar, sedangkan sisanya $62,2 \%$ dipengaruhi oleh variabel lain. Pada sarana pendidikan sebesar 2,95\% dapat dikatakan sarana pendidikan berpengaruh terhadap prestasi belajar, sedangkan sisanya 70,5\% dipengaruhi oleh variabel lain. Maka yang paling dominan dalam penelitian ini ialah pada indikator sarana pendidikan yaitu $37,8 \%$.

Tabel 2. Uji Determinasi

\begin{tabular}{|c|c|c|c|c|}
\hline \multicolumn{5}{|c|}{ Model Summary } \\
\hline Model & $\mathrm{R}$ & R Square & $\begin{array}{l}\text { Adjusted R } \\
\text { Square }\end{array}$ & $\begin{array}{l}\text { Std. Error of } \\
\text { the Estimate }\end{array}$ \\
\hline 1 & $.615^{\mathrm{a}}$ & .378 & .367 & 4.158 \\
\hline 2 & $.543^{\mathrm{a}}$ & .295 & .282 & 4.429 \\
\hline \multicolumn{5}{|c|}{$\begin{array}{l}\text { Predictors: (Constant), SaranaPendidikan } \\
\text { Predictors: (Constant), PrasaranaPendidikan } \\
\text { Dependent Variable: FasilitasBelajar }\end{array}$} \\
\hline
\end{tabular}

Sumber : Penelitian Kuesioner (2020, Data diolah)

Berdasarkan hasil penelitian dengan menggunakan SPSS 25 dapat dikatakan bahwa hasil nilai keseluruhan variabel fasilitas belajar secara simultan yang berpengaruh terhadap prestasi belajar yaitu sarana pendidikan yaitu dengan nilai $37,8 \%$ dan sisa nya dipengaruhi oleh variabel lain 


\section{Pembahasan}

Sarana dan prasarana pendidikan meupakan material pendidikan yang sangat penting. Banyak sekolah memiliki sarana dan prasarana pendidikan yang lengkap sehingga sangat menunjang proses pendidikan disekolah (Barnawi \& Arifin, 2012). Hasil analisis yang telah dilakukan yaitu dengan menggunakan analisis uji determinasi menunjukkan fasilitas belajar secara simultan yang berpengaruh terhadap prestasi belajar yaitu sarana pendidikan. Sarana dilihat dari fungsinya atau perannya dapat dibedakan menjadi alat pelajaran, alat peraga dan media pembelajaran Tatang M. Amirin, ddk dalam (Jannah, 2017). Berdasarkan hasil penelitian, Sarana pendidikan berupa alat pelajaran yang dapat digunakan mahasiswa dalam pelajaran seperti buku refrensi yang diberikan kampus, Alat belajar (buku,pulpen,dan pinsil) serta modul atau bahan ajar dosen dapat mendorong untuk meningkatkan semangat belajar mahasiswa dan mempermudah dalam proses belajar. Disamping itu, Sarana pendidikan berupa alat peraga berupa whiteboard dikelas, proyektor, dan LCD yang tersedia yang sangat memadai dapat membantu mempermudah para mahasiswa dalam proses belajar mengajar. Selain itu, sarana pendidikan berupa media pembelajaran yang berfungsi sebagai prantara (medium) dalam proses pembelajaran seperti video pembelajaran yang menarik, power point, dan buku pembelajaran memudahkan mahasiswa dalam menerima pelajaran, sehingga meningkatkan efektivitas dan efesiensi dalam mencapai tuujuan pendidikan.

Sarana pendidikan berpengaruh terhadap prestasi belajar dapat dilihat dalam tiga faktor yaitu faktor internal , faktor eksternal dan faktor pendekatan belajar. Dalam faktor internal, sarana pendidikan berpengaruh terhadap Intelegensi, sikap, bakat, minat, dan motivasi belajar mahasiswa. Dengan kata lain, sarana pendidikan dapat mendukung meningkatkan kecerdasan didalam diri mahasiswa yang menentukan tingkat keberhasilan belajar. Selain itu, mahasiswa mampu bersikap dengan baik ketika dosen menerangkan pelajaran dengan menggunakan power point serta video pembelajaran yang menarik sehingga fokus perhatian tertuju pada dosen dan merespon ketika dosen memberika pertanyaan tentang mata pelajaran yang dipelajari. Disamping itu, dengan fasilitas yang disediakan perguruan tinggi membuat mahasiswa mudah menuangkan segala bakat atau kemampuan yang dimiliki, menumbuhkan minat dan motivasi belajar sehingga selalu berusaha untuk mendapatkan prestasi.

Sedangkan faktor ekternal faktor dari luar mahasiswa yakni kondisi atau keadaan lingkungan disekitar mahasiswa yaitu lingkungan sosial dan lingkungan non sosial. Dengan kata lain, sikap dan prilaku orangorang di lingkungan perguruan tinggi maupun diluar perguruan tinggi yang baik dapat membuat mahasiswa terpengaruh untuk bersikap baik. Selain itu, faktor pendekatan belajar juga berpengaruh seperti menggunakan strategi dalam belajar dan cara-cara atau metode dalam belajar mempermudah belajar mahasiswa supaya mendapatkan hasil yang maksimal.

\section{Kesimpulan}

Berdasarkan hasil penelitian dapat disimpulkan bahwa sarana pendidikan berpengaruh terhadap prestasi belajar mahasiswa/i Politeknik LP3I Medan Kampus Marelan pada Tingkat II dan III. Dari hasil analisis diketahui bahwa sarana pendidikan berpengaruh terhadap prestasi belajar yaitu sebesar 37,8\% dimana $62,2 \%$ dipengaruhi oleh variable lain. Perguruan Tinggi memiliki peran penting dalam membangun anak bangsa karena dianggap salah satu cara untuk bisa mendapatkan kehidupan yang lebih baik di masa depan. Oleh karena itu, Perguruan Tinggi perlulah menyediakan fasilitas sarana pendidikan yang baik dan lengkap guna memenuhi kebutuhan belajar mahasiswa yang dapat berpengaruh terhadap prestasi belajar mahasiswa.

\section{Ucapan TerimaKasih}

Diucapkan terimakasih pada semua pihak yang telah berkontribusi dalam penelitian ini, sehingga penelitian dapat terlaksana dengan baik. 


\section{Referensi}

Amah, N., \& Nugroho, A. D. (2015). Pengaruh Fasilitas Sekolah Terhadap Hasil Belajar Akuntansi Dengan Lingkungan Sosial Sebagai Pemoderasi. Journal of Accounting and Business Education, 1-12. http://journal.um.ac.id/index.php/jabe/article/view/6078/2557

Barnawi, \& Arifin, M. (2012). Manajemen Sarana dan Prasarana Sekolah. Ar-Ruzz Media.

Cynthia, L. C., Martono, T., \& Indriayu, M. (2015). Pengaruh Fasilitas Belajar Dan Motivasi Belajar Terhadap Prestasi Belajar Mata Pelajaran Ekonomi Siswa Kelas XI IIS Di SMA Negeri 5 Surakarta Tahun Ajaran 2015/2016. Jurnal Pendidikan Bisnis Dan Ekonomi, 1(2). https://jurnal.fkip.uns.ac.id/index.php/ptn/article/view/7397

Dewi, E., Johan, R. S., \& Trisnawati, F. (2017). The Effect Of Learning Facility Learning Outcomes Of Class X Accounting Skills Program In SMK Kansai Pekanbaru. Jurnal Online Mahasiswa.Fakultas Keguruan Dan Ilmu Pendidikan, 4(1), 1-13.

Herlianto, J. I., Suwatno, \& Herlina. (2018). The Impact of Teacher's Professional Competence and Student's Motivation Toward Student's Achievement In Archives Subject of Office Administration In Vocational High School 1 Ciamis. Manajerial, 3(1), 23-32. http://ejournal.upi.edu/index.php/manajerial/

Islamiyah, N. (2019). Pengaruh Fasilitas Belajar dan Motivasi Belajar Terhadap Prestasi Belajar Mahasiswa Jurusan Pendidikan Ekonomi 2017 Universitas Negeri Surabaya. Jurnal Pendidikan Ekonomi, Manajemen Dan Keuangan, 3(1), 24-32.

Jannah, M. Z. (2017). Pengaruh Fasilitas Belajar Dan Motivasi Belajar Terhadap Prestasi Belajar Siswa Kelas V Pada Mata Pelajaran Matematika Di MI Bustanul Ulum Brudu Sumabito Jombang.

Martin, \& Fuad, N. (2016). Manajemen Sarana dan Prasarana Pendidikan Konsep dan Aplikasinya. Rajawali Pers.

Puspitasari, W. D. (2016). Pengaruh Sarana Belajar Terhadap Prestasi Belajar Ilmu Pengetahuan Sosial Di Sekolah Dasar. Jurnal Cakrawala Pendas, 2(2).

Said, S. (2019). Pengaruh Fasilitas Belajar Di Rumah Terhadap Prestasi Belajar Mata Pelajaran IPS Terpadu Siswa Sekolah Menengah Pertaman Negeri. Jurnal PenKoMi: Kajian Pendidikan Dan Ekonomi Vol. 2, No. 2, 2(2), 33-38.

Sugiyanto. (2015). 72 Universitas PGRI Yogyakarta. Seminar Nasional Universitas PGRI Yogyakarta, 72 79.

Syah, M. (2018). Psikologi Belajar. Rajawali Pers.

Utami, I. T. (2020). Pengaruh Fasilitas Belajar Terhadap Prestasi Belajar Pada Mata Kuliah Korespondensi Indonesi. Jurnal Sekretari \& Administrasi (Serasi), 18(2), 13-23. 